\title{
Investigating the Effectiveness of Classroom Based Assessment on ESL Teaching Strategies and Techniques in Pakistan: Study from Teachers' Perspective
}

\author{
Shabana Sartaj \\ Department of English, Sindh Agriculture University, Tandojam, Pakistan \\ Shafqat Kadri \\ University of Sindh, Jamshoro, Pakistan \\ Syed Faisal Haider Shah \\ University of Sindh, Jamshoro, Pakistan \\ Ali Siddiqui \\ English Language Development Center (MUET), Jamshoro, Pakistan
}

\begin{abstract}
Assessment plays vital role in language learning. It is responsibility of a teacher to know all aspects of assessment as it can be beneficial and harmful at the same time for students. Therefore, what to assess, how to assess and mastery of assessment tools for specific purpose is very essential for ESL teachers. The current study is based on classroom based assessment because it deals with all aspects of instructing and guidance process. Present study investigates effectiveness of CBA in improvement of teaching strategies and techniques from teachers' perspective. The study is designed on quantitative method and follows exploratory research design. The findings of the study showed that if Classroom based assessment is applied in educational institutes and proper training of assessment techniques is provided to the teacher, it can be the most beneficial assessment for both teachers and students. It will not only be the assessment of students' performance and progress but will also assess the success of teacher, teaching strategies and methods; and will hence contribute towards the betterment of educational system overall.
\end{abstract}

Index Terms - assessment, classroom teaching, perspectives, teaching strategies

\section{INTRODUCTION}

A proper and wisely used assessing do help to motivate unwilling, revise, less courage, to enhance, and straight to avoid direct assess the achieving of goal. Assessment has vital role in teaching and learning process. It is the responsibility of a teacher to know all aspects of assessment as it can be beneficial and harmful at the same time for students. Therefore, what to assess, how to assess and mastery of assessment tools for specific purpose are very essential for ESL teachers (Snow, Griffin, \& Burns, 2005).

Majority of teachers in Pakistan are unable to find out the reasons of poor teaching and learning process. Researches have emphasized that the role of teaching strategies, methods and styles is also main factor for the failure of educational system (Gipps, 1994; Rehmani, 2003). Educational system in Pakistan follows summative assessment system at majority of its institutions; the exams are held once or twice a year in which only grades are awarded not the performance or proficiency of students is assessed (Warsi, 2004; Mahboob, 2012). Due to this assessment system, teachers cannot figure out how far their teaching strategies and methods went successful, where they need improvement or change of strategy. At the same time, there is no proper or established system of teachers' professional development except for few programs that are not in access of every teacher.

Assessment is an ongoing process in which teacher and students both need to know the success of learning process with the explicit feedback during the instructions. For that purpose, the mastery of assessment skills, what to assess, how to assess is important (Snow, Griffin, \& Burns, 2005).

Through the course of history, different assessment techniques and procedures are experienced, practiced and researched. Most prominent of which are;

- Proficiency Based Assessment tests the achievement of student in certain skill, it can be normative and criterion based.

- Learning Based Assessment: Assessment of task 
- Summative Assessment is done at certain time to evaluate student's learning according to some standard or grade.

- Formative Assessment is a continuous monitoring of students' learning to make student aware of his strength and weakness as well as help teachers to find out and address the problem areas of students. It's ongoing assessment.

\section{A. Classroom Based Assessment}

CBA is continuous monitoring of students' behavior, motivation, attitudes, learning styles and teaching strategies during a class. Like formative assessment CBA is also beneficial for teachers as well as students. It can be beneficial for preparation of IELTS, TOEFL. Classroom based assessment deals with all aspects ofteaching and learning process. CBA is not only assessment of student and his achievement but also critically analyses teaching techniques and strategies of a teacher.

The current study is carried out to find the consequences of Classroom Based Assessment to the instructing strategies as well as techniques in English as second language teachers of Pakistan. The study analyses the CBA from teachers' perspectives and their professional development. Classroom based assessment or formative assessment has gained prominent importance in current education policies. According to (Looney, 2011), the Formative type of assessment has been referred as most occurring, collaborative assessment of learner's development to find learning essentials and towards shaping the teaching method.

\section{B. Background of the Study}

Teaching and learning are interrelated processes. Not only they depend on each other but have immense affect on each other. Similarly, assessment and instruction are also related components. The feedback gained through assessment plays vital role in the adoption, rejection and adaptation of certain teaching strategies and methodologies. The result of assessment is not only grading of students' achievement but also help teacher to take decisions for his teaching styles.

Since last couple of decades, there have been revolutionary changes in the system of education. Besides focusing on the learning behaviors and attitudes of students, researchers are also emphasizing on the teachers' part within getting guidance and teaching process. It is for that reason professional development related to teachers is considered as the crucial element for the education system. According to Gathon and Pestieau (1995), the instructor's growth as a professional teacher achieves with a result to gain the increased experiences as well as investigating either his or her teaching in as systematic way. The teacher is regarded as thoughtful expert, who come in the occupation with one's basic familiarity to improve it with his experiences and new knowledge gained (Cochran-Smith and Lyte, 2011). This idea of improving skills and knowledge through experiences is only possible through classroom based assessment, where you can get students' responses on the spot and reflect on the teaching styles and strategies in perspectives of the students' performance. For that purpose, knowing how to examine and what to examine is most important factor.

Unfortunately, in Pakistan there is lack of such professional development centers and institutes for teachers in general and for assessment as specific (Villegas-Reimers, 2003). Rehmani (2003) shed light on different issues in the assessment system of Pakistan and concluded that assessment and examination system in Pakistan has more demerits than merits. Institutes like Agha Khan University, Society of Pakistani English Language Teachers and Higher Education Commission of Pakistan are taking efforts in this direction but they are not in access of all Pakistani teachers.

\section{Objectives of the Study}

Present study is carried out to figure out the assessment strategies in Pakistan from teachers' perspectives in general. Specifically the study focuses on classroom based assessment, its usage and teachers' perception for CBA. It focusses on how far CBA is beneficial for teachers. Specific objectives of the study are to find out;

1. The general views of teachers about the assessment system in Pakistan.

2. The usage of classroom based assessment and perceptions of teachers for that.

3. Advantages of CBA for improvement of teaching strategies and methods.

\section{Research Questions}

The research questions are designed on the basis of research objectives:

1. What are the general views of teachers about the assessment system of Pakistan?

2. How far CBA is used in classrooms and what are teachers' perceptions about CBA?

3. How far CBA is beneficial for improvement of teaching strategies, styles, and methods?

\section{LITERATURE REVIEW}

\section{A. Classroom Based Assessment}

The debate of Classroom based assessment started with the publication of Black and Wiliam's (1998) phenomenal article on classroom formative assessment. The study of opened the new spheres in assessment strategies and fetched interest of academicians and researchers towards classroom-based assessment (CBA) and its potential for enhancing learning. In order to understand the phenomenon of Classroom based assessment, it is essential to understand the relationship between learning, teaching and assessment techniques used (Perron, 2011). It is through implementing various strategies of assessment that teachers collect information about the success or failure of their teaching styles, 
methods or decision making about the classroom instructions (Purpura, 2009). According to Purpura (2007, 2009), the information collected in assessment and observations determines the confirmation of comprehension and learning gaps in classroom; hence, teachers subsequently incorporate more intervening and improvised teaching strategies.

\section{B. Teacher \& Classroom Based Assessment}

Although the research has acknowledged the importance of learner in assessment, (Andrade, 2010), it is nonetheless recognized that teachers still have an important part to play in the process (Purpura, 2009). Hence, the importance of teacher has gained increasing concerns towards using assessment for accountability purposes (Leung \& William 2014; Malone, 2013) as well as the widespread introduction of policies to implement assessment-for-learning principles in curriculum and assessment (Fulcher, 2012; Leung, 2014). These developments have focused attention on teachers' capacity to deliver assessment reforms, with teacher assessment literacy (TAL) identified as a critical factor in improving student learning (Hattie, 2012).

\section{Role of CBA in Language Acquisition}

The importance of Classroom based assessment has not only been acknowledged in learning and comprehension (Cheng, 2005; Wall, 2001) but has also been examined as main factor in to promote second language acquisition (ReDickens, 2008). A lot of research has been conducted on the impact of CBA on EFL learners and second language acquisition (Perron, 2011; Purpura, 2004, 2006, 2007, 2009; Re-Dickens, 2001, 2004, 2013). A detailed study of these researches will enable teachers to comprehend the relationship between CBA and language learning and acquisition.

Most state certification systems and half of all teacher education programs have no assessment course requirements, nor do they have an explicit requirement that teachers have received training in assessment (Boothroyd, 1992; Trice, 2000; Wise, 1991). Soon after, Bloom (1968) and Bloom, Madaus and Hasting (1971) took up this idea, applying the concept to student assessment in their work on "mastery learning". They initially proposed that instruction be broken down into successive phases and students be given a formative assessment at the end of each of these phases. Teachers would then use the assessment results to provide feedback to students on gaps between their performance and the "mastery" level, and to adjust their own teaching to better meet identified learning needs (Allal, 2005).

\section{Classroom Based Assessment in Pakistan}

Warsi (2004) and Kenan (2006) termed the assessment system in Pakistan as examination of rote memorization. According to them, the language assessment in Pakistan is not assessing or testing the concrete skills of students but it is the test of their cramming. Whereas the objectives of the examination and the nature of assessment determines the approaches of teaching and learning (Rehmani, 2003). The primary objective of an assessment is towards facilitating processes of teaching and learning by gaining feedback from the results (Gipps, 1994). Rehmani (2003) argued in his study on public examination in Pakistan that assessment in Pakistan will play significant role if it is conducted for the improvement of education, teaching learning approaches and it is only possible with the blend of summative and formative assessment. Similarly, L.D Fink (2003) proposed a model of course designing emphasising that assessment should be the main element of any course design and it is critical for students and teachers to know whether the goal is teaching is accomplished or not. Fink (2003) argued that assessment is not only the tool of "Audit-ive assessment" to assign only grades but should be "Educative assessment" to measure whether students got it and teacher realized his/her weakness and strength in teaching process.

English, being the official and foreign language in Pakistan has critical role in educational, professional and official system. Hence, learning of English has become vital part in society and named as social symbol by researchers (Rehmans, 2008; Shamim, 2011). So, the understanding and training of Classroom based assessment can be beneficial for both students and ESL teachers.

\section{METhodology}

This study followed the Mixed Method Research approach looking at the nature of the study. Mixed method is an approach where researchers employ strategies to collect data numerical and text based to better understand the research problem. From 1977 to 2008 there have been seen a rise in number of studies carried out on mixed methods approach and it is gaining recognition in recent studies (Plano Clark, 2008; Tashakkori \& Teddlie 2003). It is observed since beginning that there has been drawn a distinction between qualitative and quantitative method (Cohen, Manion \& Morrison2000) while it is considered as a "continuum rather than a dichotomy" (Brown 2004). This approach is popular nowadays in social, behavioural and health sciences where researcher collect data on both qualitative and quantitative methods in a single study to answer the research questions of the study better. Creswell (2003) makes it clear in words, "It employs strategies of inquiry that involve collecting data either simultaneously or sequentially to best understand research problems.

As mentioned earlier, the objective of this study is to explore the perceptions of teachers for classroom based assessment as the tool to improve their teaching strategies and methods. Moreover, it also highlights the general perceptions of teachers for the assessment at educational system of Pakistan. Considering the genre and objectives of the study, in quantitative part a questionnaire was used as research instrument to collect the data. The respondents were 
given questionnaire about the assessment in general, assessment at Pakistan, their views and experiences of assessment and usage and perceptions about CBA. It is already mentioned in problem statement, that summative assessment is the main type of assessment all over Pakistan and all public and private sector universities. Keeping this idea in mind, in qualitative part of the study only those respondents were selected and interviewed who use and practice CBA in their class. The semi structured interview focused only on CBA and respondents' perceptions for this type of assessment. Items of the questionnaire and interview were based on the following major themes.

\section{A. Questionnaire \& Interview Themes}

- Assessment

- Types of Assessment

- Relationship between Assessment and Strategies

- Students' Motivation, Learning Styles and Behavior

- Outcomes \& Flexibility in Change of Teaching Strategies

\section{B. Participants of the Research}

For this study, 20 ESL teachers (both male and female) of district Hyderabad of Pakistan were selected as respondents for the questionnaire. Hyderabad has 5 Major Government universities and other higher education institutes. Each institute comprises of well established English department and three of them offer bachelor to PhD degrees in English Linguistics and Literature. Out of the twenty ESL teacher participants, four respondents were selected for further interviews based on their usage of CBA in their class. Hence, the Four respondents ( 2 male and 2 female) were selected for further qualitative part of the research and semi- structured interviews.

\section{FINDINGS}

As mentioned earlier, the study was based on mixed methods research design. The data gathered from the questionnaire is presented in tabular form as follow.

The Table 1 shows the responses of ESL teachers towards the satisfaction for assessment system in Pakistan. The data depicts clearly that $60 \%$ of the respondents consider it unsatisfactory, $20 \%$ of the participants of this study consider it as a test of rote learning and $20 \%$ are satisfied with the assessment system in Pakistan. Hence, it can be concluded from the findings that majority of the teachers showed dissatisfaction with the assessment system in Pakistan.

TABLE I.

SATISFACTION WITH ASSESSMENT IN PAKISTAN

\begin{tabular}{ll|l|l|l|l}
\hline & Frequency & Percent & Valid Percent & Cumulative Percent \\
\hline \multirow{4}{*}{ Valid } & 4 & 20.0 & 20.0 & 20.0 \\
\cline { 2 - 6 } & Satisfactory & 12 & 60.0 & 60.0 & 80.0 \\
\cline { 2 - 5 } & Unsatisfactory & 4 & 20.0 & 20.0 & 100.0 \\
\cline { 2 - 5 } & Test of Rote Learning & 20 & 100.0 & 100.0 & \\
\hline
\end{tabular}

The training of teachers after appointment is the major debate in Pakistan. Although the importance of it is being highlighted on different forums but no step is taken in this regard. Currently, Higher Education Commission of Pakistan is organizing different workshops for Higher Education Institutes. The data in Table 2 shows that 55\% of the respondents have got training on assessment procedures and techniques while $45 \%$ of the respondents have not got any training on the assessment anywhere before joining the duty or on the duty.

TABLE II.

TRAINING OF ASSESSMENT

\begin{tabular}{ll|l|l|l|l}
\hline & Frequency & Percent & Valid Percent & Cumulative Percent \\
\hline \multirow{2}{*}{ Valid } & Yes & 11 & 55.0 & 55.0 & 55.0 \\
\cline { 2 - 5 } & No & 9 & 45.0 & 45.0 & 100.0 \\
\cline { 2 - 5 } & Total & 20 & 100.0 & 100.0 & \\
\hline
\end{tabular}

Similarly, the question no 3 inquired about what type of assessment method is used in the relative institute of the respondents. The responses were in alignment with the literature review on the assessment system of Pakistan. Majority of the respondents i.e 50\% (as seen in Table:3) confirmed that summative assessment system is followed in their respective institutions. While $25 \%$ of the respondents stated formative assessment and $25 \%$ stated classroom based assessment as the mode of assessment in their institutes. 
TABLE III.

ASSESSMENT MODES PRACTICED B Y PARTICIPANTS

\begin{tabular}{ll|l|l|l|l}
\hline & & Frequency & Percent & Valid Percent & Cumulative Percent \\
\hline \multirow{5}{*}{ Valid } & Summative Assessment & 10 & 50.0 & 50.0 & 50.0 \\
\cline { 2 - 6 } & Formative Assessment & 5 & 25.0 & 25.0 & 75.0 \\
\cline { 2 - 6 } & Classroom Based Assessment & 5 & 25.0 & 25.0 & 100.0 \\
\cline { 2 - 6 } & Total & 20 & 100.0 & 100.0 & \\
\hline
\end{tabular}

The Table 4 shows the data for the level of satisfaction of ESL teachers with their teaching methods. The data show that majority of the respondents have opted for the average of $40 \%$ to $70 \%$ level of satisfaction with their teaching methods and strategies. $20 \%$ of the respondents fall in $10 \%$ to $40 \%$ level of satisfaction while $25 \%$ are highly satisfied ( $70 \%$ to $100 \%$ ) with their teaching methods and strategies.

TABLE IV.

PARTICIPANTS' CONFIDENCE ABOUT THEIR TEACHING Methods

\begin{tabular}{ll|l|l|l|l}
\hline & & Frequency & Percent & Valid Percent & Cumulative Percent \\
\hline Valid & $40 \%$ to $40 \%$ & 11 & 20.0 & 20.0 & 20.0 \\
\cline { 2 - 5 } & $40 \%$ to $70 \%$ & 55.0 & 55.0 & 75.0 \\
\cline { 2 - 5 } & Total to $100 \%$ & 20 & 25.0 & 25.0 & 100.0 \\
\hline
\end{tabular}

In response to the usage of CBA in classroom, the respondents showed higher positive response towards using CBA. $50 \%$ of the respondents stated that they use CBA in class, $40 \%$ use CBA sometimes in class, 5\% rarely use CBA in class while $5 \%$ never used CBA in classroom activities. The figure 4 can be seen for the presentation of the data.

TABLE V.

USAGE OF CBA IN CLASSROOM BY PARTICIPANTS

\begin{tabular}{ll|l|l|l|l}
\hline & Frequency & Percent & Valid Percent & Cumulative Percent \\
\hline \multirow{5}{*}{ Valid } & 10 & 50.0 & 50.0 & 50.0 \\
\cline { 2 - 6 } & Yes & 1 & 5.0 & 5.0 & 55.0 \\
\cline { 2 - 5 } & Sometimes & 8 & 40.0 & 40.0 & 95.0 \\
\cline { 2 - 5 } & Rarely & 5.0 & 5.0 & 100.0 \\
\hline
\end{tabular}

The aim of this study is to investigate the effectiveness of CBA for teaching methods and strategies and it is also clear that $\mathrm{CBA}$ is not only the continuous assessment of students' performance but also teaching strategies of the concerned teacher too. Once we have the data of the usage of CBA in classroom, it is essential to know whether respondents reconsider their teaching in light of the classroom assessment or not. The figure 5 shows the significant results in this regard. Almost $65 \%$ of the respondents reconsider their teaching style and methods in light of the result of classroom based assessment. Whereas, $25 \%$ respondents reconsider their teaching sometimes, $5 \%$ rarely change and $5 \%$ don't change at all. The findings of the data highly signify the importance of CBA for improvement and betterment in the teaching as in CBA teachers get on spot result of their strategies.

TABLE VI.

RECONSIDER TEACHING STRATEGIES AFTER FEEDBACK

\begin{tabular}{|c|c|c|c|c|c|}
\hline & & Frequency & Percent & Valid Percent & Cumulative Percent \\
\hline \multirow[t]{5}{*}{ Valid } & Yes & 13 & 65.0 & 65.0 & 65.0 \\
\hline & No & 1 & 5.0 & 5.0 & 70.0 \\
\hline & Sometimes & 5 & 25.0 & 25.0 & 95.0 \\
\hline & Most of the Time & 1 & 5.0 & 5.0 & 100.0 \\
\hline & Total & 20 & 100.0 & 100.0 & \\
\hline
\end{tabular}

Table 7 shows the most important finding of the data that better relates and narrates the rationale of this study. In response to the question who is responsible for the failure or bad result of students, $45 \%$ respondents blamed educational system of Pakistan, $40 \%$ responded teaching methods and strategies as responsible whereas $15 \%$ think that faulty assessment system is responsible for this failure.

TABLE VII.

RESPONSIBLE FOR FAILURE

\begin{tabular}{ll|l|l|l|l}
\hline & & Frequency & Percent & Valid Percent & Cumulative Percent \\
\hline \multirow{2}{*}{ Valid } & Teaching Methods/Strategies & 8 & 40.0 & 40.0 & 40.0 \\
\cline { 2 - 6 } & Educational System & 9 & 45.0 & 45.0 & 85.0 \\
& Faulty Assessment System & 3 & 15.0 & 15.0 & 100.0 \\
& Total & 20 & 100.0 & 100.0 & \\
\hline
\end{tabular}




\section{A. Analysis of Semi Structured Interviews}

As mentioned earlier, the study is based on mixed methods research paradigms. The qualitative part of the study is based on the interviews conducted from the ESL teachers that use CBA in their classes. The analysis of the interview was done on thematic pattern. The themes are generated from the data obtained from the respondents. The findings are discussed thematically as under;

1. Usage of CBA in Class

The usage of proper tool for specific assessment is the crucial part of the learning and assessment. The participants of the study, who use classroom based assessment had different views about the assessment techniques in CBA. For example, Participant D mentioned that oral presentations in pair or group work at the end of the class is the best way to assess the students' learning in the class. She further added that,

"Since students enjoy pair and group work activities, it is the better and productive technique for me to see whether I am doing well in class or my teaching needs more improvement."

Likewise, participant $\mathrm{C}$ favoured the oral quiz or short questions at the end of the class. Whereas participants $\mathrm{A}$ and B stated that a she used written test, task, formative and diagnostic test and emphasised that through these tools students' classroom performance and learning can be assessed in fair way. Somehow different perspective was presented by participant E. According to him,

"As teachers, we must promote activity based learning and task based activities should be made mandatory......during these activity the observation as a tool of assessment would better explain the interest, difficulties, shortcomings of students."

All the five respondents use different types of techniques in class to assess students' classroom learning. It shows that few of the teachers are willing to use assessment techniques that better benefit the students and teaching and learning process.

2. Impacts of CBA on Students' Performance; Teachers' Perspective

The main purpose of the Classroom Based Assessment is to guide the learning of students to right direction. Hence, the respondents were also questioned whether the CBA enriches the performance of students or not. Most of the respondents gave positive views about the improvement and polish of students' performance in Classroom Based Assessment. Respondent A explained the scenario in words;

"During classroom work, the observation and assessment of teacher is very essential as teacher notes the rights and wrongs of students, he then tries to correct the misinterpreted concepts of learning."

On the other hand, respondent B was of the view that CBA gives more chances of learning to students as teachers assess them during and after the lecture completion and try to fulfil the gap left by him/her. (teacher). Respondent $\mathrm{C}$ illustrated the impact of CBA in following words.

"CBA is a light of learning for both teachers and students. With this teacher improvises his/her strategies but indirectly that also is for the betterment of students as in the end, they are the real beneficiaries of the process."

The data of the research indicates that all the respondents were satisfies with the performance of their students in CBA and mentioned that their students perform well in their final tests also as they have already been assessed and given feedback in the class.

3. Impact of CBA on Teaching Strategies

As discussed earlier, the main objective of the study was to investigate the impact of CBA on the teaching strategies of ESL teachers. the quantitative part of the study shows that most of the teachers change heir teaching strategies after analysing the response of the students. In qualitative part the focus will be given that how CBA helps them improvise and improve the teaching strategies. In response to the question that how respondents assess that their teaching strategies are successful or need to be changed, the ESL teachers responded differently. For example, respondent A told,

"Students' feedback, result in class test, response of students shows the quality of a teachers' teaching strategies."

While respondent B expressed,

"Students' interest, behaviour and positive response shows the success of teaching style"

According to respondent $\mathrm{C}$,

"The relevancy of students' questions in the class shows the understanding of student and hence the success or failure of teaching method or strategy."

Participant D and E however had somehow same opinions as,

Students' classroom performance, achievement of lesson outcomes (D) feedback and classroom response of students $(E)$ indicates the productivity of the teaching method or technique.

In response to the question of impacts of CBA on teaching strategies, respondents gave positive feedback. All the respondents were of the view that CBA leads them towards the assessment and analysis of their teaching strategies as well. Eg. Participant A discussed;

"Moslty teachers use traditional, lecture methods in class but I felt students were not participating in

ESL class and most of the ideas were not clear to them, then I tried to change the style"

Participant B added; 
"I observed that rather than individual assignments and task, students participated and learn more effectively in pair, group work and discussion so I adopted more activities that had collaborative learning."

Similarly, the views of participants C,D and E also indicated towards the same point. It was seen in data that ESL teachers learn a lot through CBA and try different strategies to be productive in the class.

\section{B. Discussion}

The data revealed that majority of the teachers showed dissatisfaction with the assessment system in Pakistan. According to the responses, since beginning, in government sector schools and colleges summative assessment system is followed in which once or twice exam is held and students are judged on their cramming and on their performance. The finding also showed that in most of the institutions/universities the same system is followed, in which two semester examination is held and that is also summative. It was also seen that assignments and presentations are also held to see the progress of the students.

The data also indicated that majority of the respondents have not got any professional development training or assessment training. It was also found that most of the respondents consider educational system responsible for the poor result of the students. Despite the lack of trainings and professional development, respondents showed their interest in the assessment in shape of assignments, class presentations, competitions by which they could assess students' interest and progress towards learning. Results also showed that there is no daily or activity based assessment used in the classes except few of the responses.

When it comes to the success of teaching strategies and interest of students in class and teaching method, there comes very diverse and confused responses. For example, one of the respondents was of the view that students' interest and participation is the proof of success of his teaching strategy. While another respondent said that students' overall good result is proof of his success. But there is no strong and solid reason or assessment that proves the success of their teaching method.

\section{CONCLUSION}

The following research was conducted in order to explore the efficiency of classroom based assessment on improvement of ESL teaching strategies and techniques. Mostly all studies are carried out from students and their performance perspectives. The aim of this study was to see how helpful CBA is for teachers and the improvement of teaching strategies and methods. Findings of the study showed that despite the lack of resources, trainings, professional development skills, teachers still believe that the effectiveness to assess for process within learning and teaching procedures. Teachers' views proved that learning and teaching are interlinked process and hence, the idea of Snow, Griffin, \& Burns (2005) is validated that for the success of this process mastery of assessment skills is compulsory.

Findings of the study also show that if Classroom based assessment is imposed in educational institutes and proper training of assessment techniques is provided to the teacher, it can be the most beneficial assessment for both teachers and students. It will not only be the assessment of students' performance and progress but will also assess the success of teacher, teaching strategies and methods

\section{RECOMMENDATION}

In light of the data collected and findings, there are two major recommendations for the education policy makers, administrators and government. The first one is the need of professional development of teachers in general and assessment in particular. Although there are few institutes working for professional development but looking at the population of Pakistan and need for improvements in educational sector, more institutes with better professional skills is need of time.

The 2 nd recommendation is the need to go ahead of summative assessment and encourage teachers for the specific assessment styles needed to achieve specific objectives. The journey towards new and modern assessment techniques can bring new trends in teaching methods and hence contribute towards the betterment of education system of Pakistan.

\section{REFERENCES}

[1] Allal, L. and Mottier Lopez, L. (2005). Formative assessment of learning: A review of publications in French. In Formative Assessment: Improving Learning in Secondary Classrooms, pp 241-264. Paris: Organisation for Economic Co-operation and Development.

[2] Andrade, H., \& Cizek, G. J. (2010). Students as the definitive source of formative assessment: Academic self-assessment and the self-regulation of learning. In Handbook of formative assessment (pp. 102-117). Routledge.

[3] Black, P., \& Wiliam, D. (1998). Inside the black box: Raising standards through ASCD https://www.ascd.org/portal/site/ascd/template.MAXIMIZE/menuitem.4... 5 of 5 9/11/2008 12:25 PM classroom assessment. Phi Delta Kappan, 80(2), 139-148.

[4] Bloom, B. S. (1968). Learning for mastery. Evaluation Comment (UCLA-CSIEP), 1(2), 1-12.

[5] Bloom, B. S., Madaus, G. F., \& Hastings, J. T. (1971). Handbook on Formative and Summative Evaluation of Student Learning. New York: McGraw-Hill. 
[6] Boothroyd, R. A., McMorris, R. F., \& Pruzek, R. M. (1992, April). What do teachers know about measurement and how did they find out? Paper presented at the annual meeting of the National Council on Measurement in Education.

[7] Burn, J., \& Thongprasert, N. (2005). A culture-based model for strategic implementation of virtual education delivery. International Journal of Education and Development using ICT, 1(1), 32-52.

[8] Cohen, L. Manion, L. \& Morrison K. (2000). Research Methods in Education. London: Routledge Falmer.

[9] Creswell, J.W. (2003). Research design. Qualitative, Quantitative and Mixed Methods Approaches. Thousand Oaks, CA: Sage.

[10] Fink, L. Dee. (2003). Creating Significant Learning Experiences. Hoboken, NJ: Jossey-Bass.

[11] Fulcher, G. (2012). Assessment literacy for the language classroom. Language Assessment Quarterly, 9(2), 113-132.

[12] Gathon, H.-J. and Pestieau, P. (1995). Decomposing efficiency into its managerial and its regulatory components: The case of European railways, European Journal of Operational Research, 80, 500-507.

[13] Gibbs, R. (1994). The poetics of mind: Figurative thought, language, and understanding. New York: Cambridge University Press.

[14] Hattie, J. (2012). Visible learning for teachers: Maximizing impact on learning. Routledge.

[15] Leung, J. H., \& Williams, J. N. (2014). Crosslinguistic differences in implicit language learning. Studies in second language acquisition, 36(4), 733-755.

[16] Looney, J. W. (2011). Integrating formative and summative assessment: progress toward a seamless system?, OECD, Education Working Papers, No.58, OECD Publications.

[17] Lynch. B (2011). Rethinking assessment from a critical perspective. Language Testing 18 (3), 33-49.

[18] Mahboob, Ahmar. (2012). Pakistani English, in: Bernd Kortmann and Kerstin Lunkenheimer (Eds.): The Mouton World Atlas of Variation in English. Berlin/Boston: De Gruyter Mouton, pp. 531 - 539.

[19] Malone, M. E. (2013). The essentials of assessment literacy: Contrasts between testers and users. Language Testing, 30(3), 329-344

[20] Perrone, M. (2011). The Effect of Classroom-Based Assessment and Language Processing on the Second Language Acquisition of EFL Students. Journal of Adult Education, 40(1), 20-33.

[21] Plano Clark, V. L., \& Creswell, J. W. (2008). The mixed methods reader, Thousand Oaks, CA: Sage.

[22] Purpura, J.E. (2004). Assessing Grammar. Cambridge: Cambridge University Press.

[23] Purpura, J.E. (2006). Issues and challenges in measuring SLA. Colloquial presentation: Towards theoretical meaningful L2 assessment for SLA research. American Association for Applied Linguistics Conference, June 2006.

[24] Purpura, J. E. (2013). The development and construct validation of an instrument designed to investigate selected cognitive background characteristics of test-takers. In Validation in language assessment (pp. 125-154). Routledge.

[25] Purpura, J. E. (2016). Second and foreign language assessment. The Modern Language Journal, 100(S1), 190-208.

[26] Rea-Dickens, P., \& Germaine, K. (2001). Purposes for evaluation. Innovation in English language teaching, p. 253-262.

[27] Rea-Dickens, P. (2004). Understanding teacher as agents of assessment. Language Testing, 21 (31), 249-258.

[28] Rahman, T. (2004). Denizens of alien worlds: A study of education, inequality and polarization in Pakistan. OUP Pakistan

[29] Rehman, T. (2010). "English-Teaching Institutions in Pakistan." Journal of Multilingual and Multicultural Development.

[30] Rehmani, A. (2003). Impact of public examination system on teaching and learning in Pakistan. International Biannual Newsletter ANTRIEP, 8, 3-6.

[31] Sales, V. (1999). Women teachers and professional development: gender issues in the training programmes of the Aga Khan Education Service, Northern Areas, Pakistan. International journal of educational development, 19(6), 409-422.

[32] Shamim, F. (2011). English as the language for development in Pakistan: Issues, challenges and possible solutions. Dreams and realities: Developing countries and the English language, p.291-310.

[33] Snow, C. E., Griffin, P., \& Burns, M. S. (Eds.). (2005). Knowledge to support the teaching of reading: Preparing teachers for a changing world. San Francisco, CA: Jossey-Bass.

[34] Tashakkori, A., \& Teddlie, C. (2003). Issues and dilemmas in teaching research methods courses in social and behavioural sciences: US perspective. International Journal of Social Research Methodology, 6(1), 61-77.

[35] Trice, A. D. (2000). A handbook of classroom assessment. New York: Addison Wesley Longman, Inc.

[36] Villegas-Reimers, E. (2003). Teacher professional development: an international review of the literature. Paris: International Institute for Educational Planning.

[37] Warsi, J. (2004). Conditions under which English is taught in Pakistan: An applied linguistic perspective. USA: Sarid- Journal

[38] Wise, S. L., Lukin, L. E., \& Roos, L. L. (1991). Teacher beliefs about training in testing and measurement. Journal of Teacher Education, 42, 37-42.

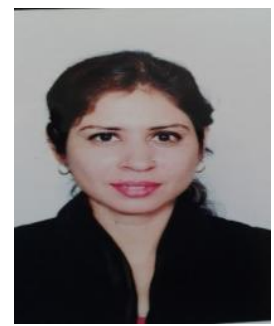

Shabana Sartaj has been serving as Assistant Professor in Department of English, Sindh Agriculture University Tandojam, Sindh, Pakistan. She has done her doctoral study from Universiti Sains Malaysia (USM) on communicative competence models of Bachman \& Palmer. She has Masters in English Literature and TEFL (Teaching of English as Foreign Language). She is supervising MS-Linguistic students' research projects as well. As a researcher, she is working further on sociolinguistic component in communication of Pakistani students at various levels. 


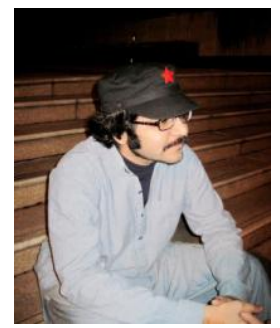

Shafkat Ali Kadri has been working as Assistant Professor in Institute of English Language and Literature, University of Sindh, Jamoshoro, Pakistan. He has done Masters in English Literature from University of Sindh and MS Linguistics from Newzealand. Currently he is doing research on language rights of indigenous people and languages in context of Pakistan. He has many written and translated books on his credit. Kadri has translated books from French, German and Persian into Sindhi language.

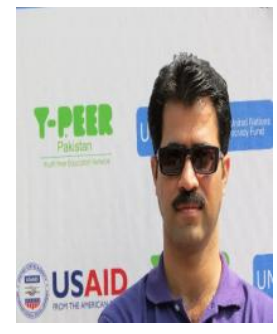

Syed Faisal Haider Shah is Assistant Professor in department of Social Work in University of Sindh. He has recently completed his $\mathrm{PhD}$ studies in challenges and Opportunities for women empowerment in higher education abroad. Faisal is working on different research projects with his students in field of social work.

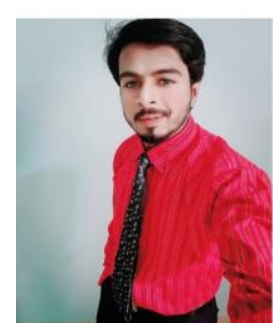

Ali Siddiqui is currently an M.S scholar of English Linguistics in ELDC, Mehran University of Engineering and Technology, Jamshoro, Sindh, Pakistan. He has done M.A (Masters of Arts) in English linguistics from University of Sindh, Jamshoro, Sindh, Pakistan with distinction (2016). The author is having research interest in English language teaching, research techniques in field of education and English for specific purposes. The Major Field of author's study is (English linguistics). 